$$
\text { studile }
$$





\title{
Alegorie a odkazy k apoštolu Petrovi v Shakespearově Romeovi a Julii
}

Petr Osolsobě

\begin{abstract}
Allegory and Allusions to St. Peter in Romeo and Juliet

The recusant culture in the time of the queen Elizabeth (1558-1603) developed a lot of rhetorical devices, figures, tropes and allegories to convey hidden religious and political meanings. Apostle Peter, whose authority had been lessened by reformers, epitomized the institution of papacy and the Roman Church for the Catholics as is clearly understandable from the poem Saint Peter's Complaint by Robert Southwell or from the motet Tu es Petrus by William Byrd. In The Tragedy of Romeo and Juliet Shakespeare creatively adapted motifs taken from his sources (Brooke, Painter) but added to them a remarkable number of allusions, canonical terms, and references to St. Peter the apostle, to the Ecclesia Romana and to Rome as well as to the liturgy of Maundy Thursday and Good Friday, thereby underlining a sacrificial value of Juliet's suffering in figura Christi for the sanctity of her marriage. This article supports the thesis that Shakespeare made use of the Bible and scholastic philosophy for his dramatic purpose, and deliberately imbued the secular subject-matter with a religious vocabulary and imagery.
\end{abstract}

\section{KEYWORDS}

Shakespeare, religion, Romeo and Juliet, drama, allegory, Bible, literary history, English recusant history.

\section{KLÍčOVÁ SLOVA}

Shakespeare, náboženství, Romeo a Julie, drama, alegorie, bible, literární historie, dějiny anglické literatury. 


\section{Dedicatio}

Profesor Milan Suchomel, náš vzácný jubilant, mi nedávno kladl na srdce: „tak už o tom náboženství v Shakespearových hrách něco napište, at̉ si to můžu přečíst". Přicházím Vám pogratulovat, pane profesore! A prosím o Vaše shovívavé přijetí jednoho z přezrálých plodů letitých úvah, nebot’ skoro vše, co bude následovat, přišlo mi jakýmsi vnuknutím jednoho večera na jaře 2006, kdy jsem psal text do programu bratislavské Astorky o hře v režii J. A. Pitínského. Je to jen malá tesera v mozaice poznání Shakespearova díla, $\mathrm{z}$ něhož budu analyzovat opomíjený detail: nadbytečné odkazy k apoštolu Petrovi v tragédii o Romeovi a Julii.

\section{Proemio}

Pokusíme se ukázat, jak dramatik záměrně obohacoval dramatický děj biblickými odkazy a náboženskými reáliemi, které vytvářejí rovinu alegorického smyslu, a činíval to i tam, kde to předloha nevyžadovala. Tento rys religiózní obraznosti dnes skoro nevnímáme a současné české překlady se s ním míjí, převážně z neznalosti, jednak i proto, že současná mluvená čeština, k níž překladatelé tak úporně lnou ve snaze „přiblí̌zit Shakespera současnému diváku“, je lexikálně zesvětštělá a výrazy jako „pokání“, „rozhřešení“, „ctnost“, „milost“ nebo „zatracení “ se v proudu moderní řeči jeví jako cizorodé archaismy. Shakespearův jazyk se totiž ubíral právě opačnou cestou; na prahu měštanského a merkantilního novověku hledí zachránit leccos z jazyka scholastické učenosti, kanonického práva a mešní liturgie a toto lexikum, spíše nežli archaismy slova latinského původu a náboženského významu, zachovat a naturalizovat ve vyšší mluvené angličtině. Například latinismy „confession“ (zpověd), „prostration“ (ponížení se), „repent“ (úkon kajícnosti), „opposition“ (zde: nesouhlas s vưlí rodičů), „remission“ (prominutí), „fact“ (čin, namísto deed) nebyly sice angličtině konce 16. století neznámé, ale fakt, že jsou koncentrovány jen do dvou vět Juliiny rozmluvy v prvním kvartovém vydání ${ }^{1}$ vypovídá o básníkových jazykových sklonech až až. Taková básnická mluva musela znít uchu řemeslníků postávajících pod prk-

1) Překlady výrazů a pasáží z Romea a Julie jsou autora článku, není-li uvedeno jinak (J. V. Sládek). Srov. pasáž z RJ v Q1 (4.2.13 passim): „Mother: See here she commeth from Confession. - Juliet: Where I have learned to repent the sin / Of froward wilfull opposition / Gainst you and your behests, and am enjoind / By holy Laurence to fall prostrate here / And crave remission of so faul a fact." 
ny Glóbu poněkud cizorodě, exoticky a rovněž i uměle, jako jazyk psaný, ale Shakespeare se jako šlechtitel jazyka nevzdal; navázal na zájem publika slyšet hru (listen the play) jako dílo mluvené, stř́idal jazykové roviny a styly, a tím obelstil sklon ke zjednodušování i k empirickému zvěcnění a zesvětštění jazyka. Přes svou vytř́ibenost zůstává srozumitelný a nikdy nesetrvává ve vulgárnosti víc, než to vyžaduje charakterizace.

Náboženský podtext nelze však hledat jen v jazyce a lexiku, ${ }^{2}$ ale především $\mathrm{v}$ signifikantních detailech a v myšlenkové stavbě promluv i celé hry. Závěry, které nám vyplynou, mohou mít význam nejen pro překlad literárního díla, ale i pro celkový interpretační přistup jdoucí ruku v ruce s výkladem politických a náboženských dějin. Předesílám, že žádné z uvedených „míst“ není samo o sobě důkazem o Shakespearově náboženském přesvědčení; spíše spolu tvoří to, čemu J. H. Newman říkal illative sense, nepřímý kumulativní důkaz, v němž každý další doklad exponenciálně umocňuje pravděpodobnost závěru, že Shakespeare žil a tvořil podle „staré víry“ a „zemřel jako papeženec“. 3

\section{Elaboratio}

Pozornost zaměřená na detail byla a je běžnou technikou politizujícího divadla podléhajícího cenzuře. Alžbětinské publikum bylo politicky rozdělené a znejištěné v základních náboženských a mravních otázkách, a proto i zvláště vnímavé. Divadlo suplovalo veřejnou rozpravu o kontroverzních oblastech, k nimž patřily oddělení Anglie od Říma (schisma) a papežství, legitimita Alžběty Tudorovny po její papežské exkomunikaci (1570), svrchovanost světského panovníka ve věcech duchovních a věčných (supremacy in spiritual and eternal), Alžbětino nástupnictví (tabuizované téma), náboženská praxe ve vztahu k slavení svátků, odpouštění hříchů, existence očistce a účinnost modlitby za zesnulé, zaopatření nemocných, platnost křtu, kult svatých a jejich přímluva a samozřejmě papežství. Pro anglické dějiny má zvláštní význam rozvod Jindřicha VIII., tudíž i otázka, zda manželství je svátost a zda je nerozlučitelné. Vzhledem ke zrušení tradičních poutí, které byly pevnou součástí života měst i venkova, zůstávala

2) Shakespearovo lexikum je příznakové například tam, kde cituje různé překlady Písma. Vedle rozšiřené Bishop’s Bible a Geneva Bible používal i katolický překlad Nového zákona, tkz. doaysko-remešský, do Anglie přivážený jezuity po r. 1582.

3) „He dyed a papist“ - zápis anglikánského arciděkana Richarda Davise (c. 1660) tvoří spolu s výrokem puritána Johna Speeda (1611) „papist and his poet“ pozoruhodné svědectví o tom, jak se Shakespeare jevil protestanským duchovním a kronikářuom. 
palčivá otázka, zda penitenciální poutě k hrobům apoštolů, ba i do Svaté země mají vůbec smysl a zda budou někdy obnoveny. A dále jedna z ústředních náboženských otázek časů reformace: je Kristus v eucharistii skutečně přítomný? Je zajímavé, že Shakespeare se porůznu všech těchto otázek dotýká, a to i tehdy, když si toho zvolená předloha nežádá, např. právě v Romeovi a Julii. Ve hře tak vzniká celá významová vrstva signifikantních detailů, často odkazů k místům, kalendáři, svátkům, liturgii, svátostem, obcování svatých, církevní architektuře nebo relikviím.

Richard Simpson, historik a objevitel problému Shakespearova náboženství, proslovil roku 1875 přednášku O večerní mši svaté v Romeovi a Julii. ${ }^{4}$ Juliina prosba otci Lorenzovi vyjádřená ve verších: „Are you at leisure, holy father, now, / or shall I come to you on evening mass?“ (4.1.38-9). „Měl byste, svatý otče, nyní volnou chvíli, anebo mám za vámi přijít na večerní mši?“ - byla dlouho považována za zjevný doklad, že Shakespeare už nebyl obeznámen s liturgickou praxí staré víry, nebot' by jinak věděl, že mše bývaly slouženy vždy jen ráno a v dopoledních hodinách. Simpson však pečlivým rozborem archivních dokumentů dokázal, že večerní mše byly na různých místech, zvláště v Itálii, slouženy navzdory zákazům, a to i př́isným nařízením papeže Pia V. (1566-72), i nadále. Zákazy, hrozící až exkomunikací, byly ostatně prosazovány velmi laxně a obcházeny především tam, kde tradice večerních mší dlouho existovala. Jedním z takových míst byla, vedle Benátek a Vercelli, i katedrála ve Veroně a mše se v ní sloužily večer až do novověku. Odkud mohl mít Shakespeare znalost takových lokálních detailů? Sám jsem dříve upozornil na jiný, dosti podobný doklad. Ve hře Zkrocení zlé ženy (4.4) připomíná Padovu jako místo kultu sv. Lukáše. To je znalost naprosto neběžná. Vybrat si kvưli lokálnímu koloritu i v Itálii vzácné patrocinium Saint Luke's church jen tak náhodou hrozilo Shakespearovi blamáží u vzdělaného a zcestovalého dvorského publika. A přece i zde byla jeho znalost náboženských reálií bezpečná. ${ }^{5}$

Jiný detail připomíná Simpson v samomluvě bratra Lorenza, který si při ranním sběru bylin připomíná: „Musím tento náš košík naplnit / bejlím i květinami vzácných štáv.“ - „I must up-fill this ousier cage of ours, / With baleful weeds,

4) SIMPSON, Richard: „On Evening Mass in Romeo and Juliet, IV,1,38“. The New Shakespeare's Society Transactions. London: Trübner \& Co. 1875, s. 148-52.

5) Srov. OSOLSOBĚ, Petr: „How Could Shakespeare Know There Was a St. Luke in Padua?“ Dnes jsou ostatky sv. Lukáše přeneseny do kostela sv. Justiny v Padově, zatímco evangelistova lebka je uložena v pokladu svatovítské katedrály v Praze. Antropologická zkoumání ze začátku 90. let 20. století potvrdila souvislost částí ostatků i pravděpodobnou dataci do 1. století po Kristu. 
and precious-juiced flowers“ (RJ, 2.3.7-8). Possesivum ours v pozici rýmového slova tu nestojí jen kvůli rýmu. Františkánská řehole i obyčej ukládaly, že bratří zasvěcení paní Chudobě se vzdávali soukromého majetku, pročež měli důsledně používat zájmeno „náš“ namísto „můj”. K čemu tak přesná charakterizace? Odkud znal Shakespeare tento detail, když františkáni byli podobně jako i jiné řehole zrušeny už Jindřichem VIII. a pro alžbětince to byla dávná minulost? ${ }^{6}$ A proč nám autor líčí řeholníky a řeholnice - v rozporu s dramatickou tendencí své doby - tak láskyplně a sympaticky a Itálii jako zemi vzdělanou a laskavou, a ne jako kazateli i dramatiky líčenou zemi úkladů, jedu, dýky a „děvky babylónské"? Proč postavy, a nejen v této hře, hovoří o řeholnících a kněžích kladně a oslovují je přídomkem holy - svatý(á)? Například Romeo říká v Lorenzovi (3.3): „[...] a ty máš srdce, ty, který jsi kněz / a zpovědník a hříchů odpustitel / a osvědčený přitel můj“" (how hast thou the heart / Being a divine, a ghostly confessor, / A sin-absolver, and my friend profess'd).

Třebaže Painterova novela o Romeovi a Julii (1566) skýtala na rozdíl od starší Brookovy rozvleklé epické básně (1562) sympatický portrét vzdělaného mnicha, nikde výslovně a nedvojznačně nepřípomíná moc kněze odpouštět hříchy tak jako Romeovo zvláštní „sin-absolver“ (jež navíc uchovává latinský termín absolutio). Chůva o Lorenzovi hovoří jako o „svatém mnichu“ (holy friar), Julie jako o „svatém otci“ a „duchovním otci“ (holy father, ghostly father), princ Eskalus jej veřejně označuje za svatého muže - (holy man). Proč vůbec, celkem dvacetkrát čteme $\mathrm{v} R J$ přívlastek holy pro zdůraznění sakrálnosti míst, postav, obřadů: svatý stánek, svatí poutníci, svatý polibek, svaté manželství, svatý obrad, svatý úkon, svatá slova, svatá Církev, svatý bratr, svatý otec, svatý františkánský rád? „Svatỹ - holy - nebylo právě slovo, které měl puritánský cenzor (Lord Cobham a jeho úředníci) v oblibě, ostatně dosud platil Alžbětin Královský výnos z roku 1559, jímž se „úředníkům ukládá a je odpovědnými činí, že nedopustí, aby nebylo hráno nic, v čem se pojednává či mluví o náboženství neb o správě věcí veřejných “. ${ }^{7}$ Avšak Shakespeare měl alibi před cenzorem, případně i pro cenzora, kdyby hru schválil; mohl by opáčit (a cenzor zase svým nadřízeným), že to je jen pravý obraz oné obskurantní a pověrečné italské bigotérie. Část publika, možná jen menší část, to však chápala zcela jinak. Cítila hlubokou nostalgii po náboženských formách

6) Shakespearovým oddávajícím knězem v Temple Graphton byl John Frith, františkán z rozpuštěného řádu bratří minoritů živící se léčbou sokolů a oficiálně vedený jako osoba „v náboženství nespolehlivá“ (unsound in religion). Byl snad Frith inspirací pro Lorenza z Romea a Julie? Srov. Milward,1973, s. 37-8.

7) Přeložený text celého výnosu in Alžbětinské divadlo I. Shakespearovi předchůdci. Bejblík, A., Hornát, J., Lukeš M., eds. Praha: Odeon 1978, s. 18. 
minulosti, které ty různé „anglické reformace“8 trvající už tři generace nenávratně odnesly pryč. V Romeovi a Julii je těchto forem zmíněna celá řada: poutě k ostatkům apoštolů, invokace svatých a prosba o jejich přímluvu, sv. zpověd, svátostné manželství, svátost oltářní, chvála žebravých řádů, litanické modlitby (orisons), sochy světců, používání kadidla a ornátů nebo detaily pohřebního ritu.

Jen málo z toho najdeme v Tragické historii Romeuse a Julie Arthura Brooka, a i to jen povšechně. Mnoho detailů Shakespeare do hry záměrně vnesl a jiné zase příznačně změnil, například, že Julie si má podle Brookova i Painterova zpracování př́iběhu vzít Parise ve středu 10. září. ${ }^{9}$ Děj hry přenesel do druhé poloviny měsíce července, nebot', jak se dovídáme z rozhovoru paní Kapuletové s Chůvou, Julii bude „za dva týdny a pár dní čtrnáct let“ a že to bude právě na Lammas-tide, ${ }^{10}$ svátek úrody slavený 1 . srpna. Témuž datu (1. 8.) liturgicky odpovídal svátek sv. Petra v okovech, a to mnozí v Shakespearově publiku jistě věděli. Nebot' San Pietro in Vincoli nebylo jen známé poutní zastavení na římském Viminalu s vězeňskými řetězy apoštola na hlavním oltáři, ale byl mu zasvěcen i kostel na nádvoří londýnského Toweru, St. Peter in Chains, přímo před nímž, anebo vedle něj na Tower Hillu, se odehrávaly popravy „velezrádců“, a v němž pak končila inhumací těla odsouzenců (včetně mučedníků pro víru Thomase Mora, Johna Fishera, Philipa Howarda aj.). Londýnský Tower je s Římem asociován osobou svého legendárního zakladatele Julia Caesara (jak se významně připomíná v Richardu III. i v apokryfní hře o Thomasu Morovi ${ }^{11}$ ) a jméno Julia Caesara zase nese jak hrdinka hry Julie, tak i měsíc, do nějž Shakespeare její děj záměrně zasadil - July. Tím jsme ovšem jen naznačili celou sít asociací a významových korespondencí, které geograficky, historicky, liturgicky a literárně spojovaly Londýn s Římem a sv. Petra s Towerem. Museli bychom rovněž připomenout, že Brutus z rodu Juliů byl podle tradice i kronik (Holinshed aj.) považován za zakladatele Británie, že Juliové legendárně pocházejí z Aeneáše a Afrodíty a že Londýn se dříve nazýval Troia Nova, Nová Trója. Je tu ovšem i další alegorická rovina: Sv. Petr v okovech byl současníkům hry alegorickým obrazem církve

8) Anglická reformace není jedinou historickou událostí, ale vleklým procesem neustálých změn trvajícím bezmála století. Srov. HAIGH, Christopher, English Reformations. Oxford: Clarendon Press 1993.

9) BULLOUGH, Geoffrey, op. cit., s. 339, v. 2070-2: „On Wensday next... the solemn day of marriage is, the tenth day of September".

10) $R J, 1.3 .16$ a 23. Je pozoruhodné, že J. V. Sládek (1899) si jako jediný z překladatelů povšiml této koincidence; Lammas-tide překládá „na svatého Petra“ a Lammas-Eve „noc před svatým Petrem“. In W. S. Tragédie I., přel. J. V. Sládek. Praha: SNKLU 1962, s. 327.

11) OSOLSOBĚ, Petr: „Sir Thomas More: Less Collaborative, More Shakespearean.“ In Pavel Drábek, Klára Kolinská and Matthew Nicholls, eds. Shakespeare and His Collaborators over the Centuries. Newcastle upon Tyne : Cambridge Scholars Press, 2008, s. 67-75 
Kristovy, jehož byl Petr náměstkem na zemi a každý další papež Petrovým nástupcem; církve žijící v pronásledování a čekající na své vysvobození. Petrínská alegorie byla umělecky zavedená a - části publika - srozumitelná, jak je patrné z děl Shakespearových současníků Roberta Southwella nebo Williama Byrda.

Primát apoštola Petra jako hlavy apoštolů a prvního v řadě papežů byl v Shakespearově Anglii, stejně jako na mnoha jiných místech Evropy předmětem intenzivní náboženské kontroverze. V sázce byla jednota křest̉anů a smysl papežství. Má světský panovník právo přisvojit si duchovní autoritu papežství a prohlásit se „hlavou ve věcech světských i duchovních“, jak to učinil Jindřich VIII. a jeho nelegitimní dcera Alžběta? Anebo se Petrův primát může právem opírat o slova, která mu adresuje Ježíš u Cesareje Filipovy: Ty jsi Petr, skála, a na té skále postavím svou církev a brány pekelné před ní neobstojí [...] Tobě dám klíče od nebeského království [...] atd., jak věřili a věří Angličané „staré víry“, římští katolíci.

Když ve svém římském cestopise líčí Topcliffưv placený špeh, udavač a pozdější dramatik Anthony Munday, který úspěšně infiltroval do exilových seminářŭ, kostel sv. Petra ve Vatikánu, nezapomene okomentovat nápis Tyjsi Petr, skála, a na téskále postavím svou Církev (Mt 16:18) v duchu reformace tak, že „onou skálou myslel pán Ježíš sebe, a ne Petra“. ${ }^{12}$ Naopak, jedna z Mundayho obětí, jezuita a básník Edmund Campion (1540-81) ${ }^{13}$, napsal z Prahy 3. 7.1577 svému př́iteli, bývalému oxfordskému spolužáku a exilovému překladateli bible Gregorymu Martinovi, při vzpomínce na Rím: „Co vůbec stojí pevně vprostřed všech těchto bídných změn, co vlastně? Ostatky svatých a Stolec Rybářùv. - Pomni, ó moudrosti!" ${ }^{14}$ Campionův obdivovatel a Alžbětin dvorní skladatel, katolík William Byrd, napsal na biblická Kristova slova šestihlasý motet Tu es Petrus (1607), který měl přirozeně třaskavý politický podtext. Byrd byl tvz. rekusant, to znamená, že odmítal docházet na anglikánské bohoslužby a raději platil za tyto absence vysoké pokuty, které jeho souvěrce často přivedly do vězení pro dlužníky.

Spor o apoštola Petra se promítal nejen do dramat a básní, ale hlavně do dobových pamfletů, kázání, politických proklamací a vládních ediktů; starověrcům symbolizoval Petr římskou církev, její jednotu a poslání - ut unum sint; v reformačním pohledu naopak byl tímto symbolem sv. Pavel, apoštol pohanů, jehož katedrála v centru Londýna ožívala zevnitř hlasy kazatelů a proklamacemi

12) MUNDAY, Anthony: The English Romayne life, 1582. London: John Lane The Bodley Head, 1925.

13) OSOLSOBĚ, Petr: „Přítomnost Edmunda Campiona v Shakespearových hrách“. In KONTEXTY, 6 / 2014. Brno: Centrum demokracia a kultury 2016, s. 52-61.

14) Cit. podle Simpsonova životopisu E. Campiona, 1867, s. 89 (1907, s. 125): „But what men have stood firm in these miserable changes, - what things? The relics of the Saints, and the chair of the Fisherman. O prudence!" 
státních výnosů, zvenčí pak hlasy knihkupců. Domnívám se, že Shakespeare byl symbolickou a urbanistickou opozicí apoštolů Petra a Pavla zaujat hned po svém příchodu do Londýna, v časech své rané tvorby (1591-1595), kdy pracoval na $R J$ a na Richardu III., hře o chladnokrevném tyranovi, který se v řeči vytrvale zapřísahává „při svatém Pavlu“ (6x ve stejnojmenném historickém dramatu).

(1) K těmto náboženským a literárním souvislostem musíme zmínit postavu, v níž se obě oblasti, náboženství a literatura, dokonale spojily: jezuitského misionáře a básníka Roberta Southwella (1561-1595), jenž skončil stejně jako Campion „pověšen, zaživa vyvržen a rozčtvrcen“ na tyburnském popravišti právě v roce uvedení Romea a Julie. Oba se nepochybně znali, byli vzdálení bratranci a v Londýně byli v kontaktu přes týž okruh katolických patronů, hraběte Arundela a Southhamptona. Shakespeare, jak prokázali mnozí badatelé (Devlin, Klause), Southwella básnicky imitoval, a i kdyby 21. února 1595 zrovna nestál a nepříhlížel na Tyburnu Southwellově popravě, básníkova hlava nabodena na kopí pak čněla ještě celé měsíce $\mathrm{z}$ ochozu londýnské mostecké věže jako varování těm, kdo se s parlamentem a královnou dosud nesrovnali ve víře. Shakespeare pod ní musel každodenně procházet cestou přes Temži do Southwarku a jeho divadel.

Southwell představuje výjimečný zjev „bridelovského“, antithetického baroka na anglické půdě, a to především jako autor Nářku svatého Petra (Saint Peter's Complaint), alegorického cyklu básní, které se odvíjejí od nářku apoštola, jenž si při zpěvu kohouta uvědomil, že zapřel Pána, a při odchodu z veleknězova dvora „hořce zaplakal“ (Lk. 22, 62-64). Figura sv. Petra tu opět představuje Rím, papežství a Ecclesiam Romanam, a proto v Southwellově podání je Petrův nářek i nářkem nad zkázou Anglie odloučené od Církve. Své básně psané v towerském žaláři věnoval „milému příbuznému W. S.“ a v předmluvě mu předeslal varování před „zneužíváním talentu“, jehož se dopouštějí básníci, kteří „ze zamilovaných bláznivin a výmyslů dělají běžný námět svých nízkých snah a tím natolik diskreditují samo básnění, že se Básník, Milenec a Lhář stávají pro mnohé slovy téhož významu“. ${ }^{15}$ Důtklivě vybízí čtenáře, snad právě nositele iniciál W. S., aby své básnictví zasvětil té poezii, jíž oplývají Písma v ústech proroků a apoštolů. Odtud hypotéza, zda se Shakespeare nepokusil vložit do Romea a Julie určité náboženské prohloubení snad i jako odpověd’ na Southwellovu výzvu a závět toho, kdo sám odešel na smrt ve stopách apoštola Petra (a vlastně i Edmunda Campiona) jako napraveného apoštola, který oplakal svá dřivější zapření Krista. Podle dobových svědectví byl Southwell tři roky před svou smrtí trýzněn samot-

15) SOUTHWELL, Robert: Saint Peter's Complaint. Imprinted by John Wolfe, London 1595. Překlad P. O. 
ným Topcliffem $v$ gatehouské věznici, a to zvláštním mučením „v okovech“ (the manacles). Zvláštní.

V předlohách narazil Shakespeare na postavu Petra, který je v Brookově podání sluhou v domě Kapuletově, kdežto v Painterově novele jako „Piero“ je věrným sluhou Romeovým. Pod tímto jménem se objevuje v prvním kvartovém vydání Shakespearovy hry (1597) jako ten, kdo s Romeem otevírá hrobku Kapuletů a nakonec svědčí spolu s otcem františkánem před vévodou Eskalem o smrti hlavních protagonistů. V pozdějších úpravách Shakespeare Petrovo jméno nahradil Balthasarem, ale zachoval je v postavě sluhy, s jehož doprovodem jde chůva sjednat Juliin sňatek. Jméno sluhy vybízelo k alegorizování: Chůva jej nechává stát u brány Kapuletova domu prŕkazem: „Petře, stůj u brány“ (Peter, stay at the gate!, 2.5.20). Básnické etymologie a denotace vlastních jmen byly alžbětincům lingvistickou vášní. Běžnému čtenáři renesanční novely bylo zřejmé, že jména nápadníků Romea a Parise odkazují k řevnivosti evropských metropolí, zvláště když v Painterovi četl, že sňatek s Parisem měl proběhnout mimo Veronu, ve „franckém městci“ - Villafranco. Podobně Petr před bránou Kapuletovou mohl sugerovat klíčníka Páně před vchodem do kostela (Cappellet = etym. kaple, chrám). Shakespeare samožrejmě běžně užíval obraz Petra - Klíčníka; srovnejme Othellovo: „Vy, paní, jež úřad opačný svatého Petra zastáváte / a střežíte bránu pekel!" (You, mistress, / That have the office opposite to Saint Peter / And keep the gate of hell!, 4.2.95) anebo v Mnoho povyku pro nic Beatricino: „[...] a tak jdu za svatým Petrem do nebe" ([...] and away to Saint Peter for the heavens, 2.1.39).

V analyzované hře Kapulet po poradě s Parisem stanoví Juliim sňatek na čtvrtek v kostele sv. Petra. Ve scéně (3.4) tento údaj zopakuje celkem pětkrát. V následující scéně to Julii oznámí matka a setká se s dceřiným emfatickým záporem a přísahou: „při svatém Petru i při jeho chrámu (Církvi) / neučiní mne svou štastnou paní“ (3.5.116), nebot je již tajně provdána. Petrovo zasvěcení kostela i čtvrteční den se tak znovu dvakrát připomenou. O dvacet veršů dále si bere slovo Kapulet a svi̊j rozkaz doprovodí výhrůžkou: „Bud’ příští čtvrtek s Parisem do chrámu svatého Petra půjdeš, anebo tě tam na houžvi dovleku!“ (...I will drag thee on a hurdle!) ${ }^{16}$ Tak se údaj o místu a dnu svatby, světci i kostele opakuje celkem čtrnáctkrát.

16) „Hurdle“ bylo slovo velmi konkrétní a obávané; byly to alžbětincům dobré známé proutěné sáně, na nichž byl po zemi vlečen přivázaný zločinec z vězení na místo exekuce, nejčastěji z Toweru nebo z New Gate na Tyburnskou šibenici. Takto byl vláčen před čtrnácti lety Campion, v roce pravděpodobného uvedení Romea a Julie i Southwell. 
Pokud vím, nikdo se dosud nepokusil o hlubší vysvětlení tohoto záměrně zdůrazněného detailu. Geograficky je Verona místem kultu dvou Petrů, již tu mají svůj kostel, Petra apoštola a Petra Veronského. Pro Shakespeara bylo nepochybně důležitější významové spojení s římským apoštolem. Má se snad Julie křivopřísežně dopustit druhého sňatku s Parisem a ještě v kostele zasvěceném apoštolu Petrovi, k uctění jehož ostatků poutníci-romeové putují do Řima?

Označení toho, kdo putuje k ostatkům svatých apoštolů do Věčného města, jako romea bylo rozšířené a tuto tradici zaznamenal už na konci třináctého století Dante Alighieri v závěru Nového života („romei in quanto vanno a Roma“, Vita nuova XL,7). Sémantiku hrdinova jména Shakespeare nejdříve připomene Juliiným oslovením Romea „Good Pilgrim“, a pak dokonale orchestruje v rámci „poutnického sonetu“, který tvoří repliky prvního rozhovoru Romea a Julie při jejich setkání na plese. Celý sonet by stál za zvláštní rozbor, nebot je lexikálně i sémanticky naplněn připomínkami tradičních devocionálních forem: Julie je v něm Romeem představena coby svatostánek (holy shrine) a světice (saint) i sama její socha, k níž se obracejí v modlitbách ruce poutníků (pilgrims, palmers) s prosbou o vyslyšení a očištění hříchů (1.5.90-106). Dramaticky zásadní je až dějství druhé a v něm tajná svatba obou milenců ve scéně, kterou oddávající kněz otevírá slovy: „Tak at’ se usmívají nebesa na svatý obřad ten“ (holy act), a pak ukončuje přípravy zdůrazněním, že svatá církev oba vjedno vtělí (holy church incorporate two in one, $R J$ 2.4.1-2; 35). Básník záměrně zdůrazňuje svátostný a mystický charakter manželství, a tím i jeho nerozlučitelnost. Proudy evropské reformace jednomyslně odmítaly počítat manželství mezi svátosti, což mělo pro Anglii fatální politické následky.

Vrat’me se $\mathrm{k}$ přesunutí druhého, vynuceného sňatku ze středy na čtvrtek a k významu „Petrova chrámu“.

Liturgicky je čtvrtek dnem ustavení oltářní svátosti chleba a vína, kterou Romeo i Julie přijali při svém tajném sňatku, a dnem osamělé agónie v Getsemanech. Julie se nechce, a ani nesmí podvolit vůli rodičů vzít si jimi vybraného ženicha. Kapulet vzpurnou Julii zapřísahá „při Božím chlebě!“ (God’s bread!) Nejdřive se Julie zříká matka, když jí popřeje, aby „se blázen oženil s jejím hrobem“. Pak zuřící Kapulet: „Bůh mi dopřál jen toto jedno dítě, avšak ted’ vidím, že i to je př́liš!“ (3.5.165-6) Nakonec se Julie sama odvrací od chůvy, jež jí, bezpochyby z lásky, avšak pohoršlivě nabádá $\mathrm{k}$ druhému sňatku, čímž ukazuje, že „nemá na zřeteli věci Boží, ale věci lidské“ (Mt 16:22). Julie chůvu kárá podobnými 
slovy, jimiž Kristus vyplísnil Petra: Julie: „Ó dávné prokletí! Ó nejprolhanější dáble!“ (3.5.235). Na to se Julie odebere k Lorenzovi „vyzpovídat se a požádat o rozhřešení“. Mimochodem, současné české překlady prozrazují hrubou nevědomost, když Juliina slova omylem vztahují na bytost chůvinu: „Vykopávka z pekla! Bába proradná!“ (Hilský), kdežto jsou míněna (podobně jako Kristova slova Petrovi) o Satanu jakožto duchu, který vzdoruje Božímu plánu a jehož Petr i Chůva mají per imitationem, nikoli per naturam, čili jsou mu podobni v konkrétním úkonu, ne svou přirozeností. Apostrofa „dávné prokletí!“ (ancient damnation) se nevztahuje na chůvinu fyzickou starobu, nýbrž na pád prvních lidí v ráji svodem d’áblovým. Starší překlady v tom nikdy nechybují: „Starý vrahu!“ (Doucha), „Ó staré zatracení! Hnusný d’áble!“ (Čejka), „Ó staré zatracení, d’áble zlý!“ (Sládek) - Avšak moderní: „Ty ježibabo! Ženská zkažená!“ (Josek). ${ }^{17}$

I další okolnosti jsou alegoricky víceznačné. Lorenzo dává svůj destilát s tím, že „se probudí jako z př́ijemného spánku“. A pak, že k ránu přijde „ženich“ (bridegroom) a „zvedne ji z jejího lože, na němž ležela mrtvá (4.1.107-8). Verše „[...] when the bridegroom in the morning comes / To rouse thee from thy bed, that are thou dead“ nesou alegorický význam, třebaže Lorenzo je takto nemíní. Ženich pozvedající dívku-nevěstu ze smrti k životu je alegorií Krista Vykupitele. Než Julie požije lektvar, posílá pryč chůvu, aby se mohla ve své komưrce á Getsemany, celou noc modlit, nebot’ „mám zapotřebí mnoha proseb“, aby přiměla nebesa, „aby se usmála na můj stav“. Neironické použití výrazu orisons, místo obvyklého prayers, znamená jednoznačně katolický způsob modlitby (litanie apod.), který reformátoři obviňovali z neužitečné mnohomluvnosti pohanů, citujíce přitom Mt 6:7. Julie věří, že její ženich ji přijde z hrobky „vykoupit“ (to redeem).

Nastal čtvrtek. Ráno Kapulet budí dům (4.4.3): „Kohout podruhé zakokrhal. Už zvonili. Je třetí hodina." Podle církevních hodin je to tercie od ranního rozbřesku. Má-li prostředek působit čtyřicet dva hodin, probudí se Julie po půlnoci v noci na sobotu.

Další odkazy k Zelenému čtvrtku následují: „Dříve než kohout dvakrát zakokrhá, třikrát mne zapřeš“ (Mk 14:72). Kapulet nabádá ke spěchu a chce, aby zavolali „Petra“, který „ukáže, kde jsou susší polena na oheň“, avšak druhý služebník odpovídá, že „má hlavu, která najde polena“ a „není třeba kvůli tomu volat Petra“. (Narážka, že apoštol Petr se hřál u ohně před svým zapřením? - Mk 
14:66, Lk 22:56). Kapulet vyplísní pomalého sluhu, který má donést suché dříví: „Při mši svaté“ (sic!: Zelený čtvrtek = den ustavení mše svaté), „dobře řečeno, veselý zkurvysynu, cha! Seš dubová palice, na mou věru, tento den!“ (Mass, and well said; a merry whoreson, ha! Thou shalt be logger-head. Good faith, 'tis day, 4.5.18-20). Ze spojení trámů (logs) a hlavy (head) se v kontextu Velkého pátku nutká představa ukřižování. Zároveň jde o vulgární slovní vtip: blockhead $=$ dubová palice. Kapuletovo zvolání: „Ženich už přišel!“ se týká Parise, ovšem Shakespeare dává do úst svých postav záměrně mnohoznačné dekripce, jejichž rozsah a hlubší význam si samy neuvědomují. Kapulet později sám ženicha identifikuje se Smrtákem (Death), který ženicha - Parise, předešel. Avšak nezapomínejme, že Bridegroom je rovněž jedním z Kristových eschatologických titulů.

Chůva vchází vzbudit Julii do její ložnice a přitom na ni volá: „Beránku!“ (Lamb), v prvním kvartovém vydání (Q1) dokonce opakovaně. Chůva a po ní všichni ostatní propuknou v pláč a nářek nad mrtvou dívkou. Kapulet je Juliinou smrtí otřesen, promění se a propuká v pašijovou lamentaci, v níž zaznívá doslovná ozvěna proroctví Izaiášových o utrpení Páně (Iz 53:3-10), která se čtou vždy na Velký pátek ${ }^{18}$ : „Opovržená, usoužená, znenáviděná, umučená, zabitá.“ - Despised, distressed, hated, martyred, killed! (4.4.86)

Juliina identifikace s mučednicí výrazem martyred byla už dřive víc než naznačena v duchovním rozhovoru s Lorenzem, jemuž vyjevila odhodlání raději umřít jako neposkvrněná manželka všemi možnými způsoby smrti než si vzít Parise. Tyto způsoby upomínají totiž na mučednictví, nikoli na sebevraždu z neštastné lásky: „Ó spíš než Parisovi ruku dát / mi poruč, bych se vrhla s cimbuří / té věže tam neb vyšla na cesty, / kde zloděj číhá; aneb rozkaž mi / dlít s hady; ke řvoucímu medvědu / mne přikovej; neb v noci do kostnice / mne zamkni plné kostí chřestících/ a ztuchlých hnátů, lebek bez čelistí; / neb kaž mi ulehnouti v nový hrob / a s umrlcem se ukrýt pod rubáš. Vše [...] chci učinit / hned bez úvah a strachu, čistou ženou / bych zůstala jen sladké lásce své."19

Týž mnich, který předtím ve své cele vyslechl rozhodné Juliino vyznání, přichází nyní ke Kapuletům utěšit pozůstalé a radí, aby na Juliino mrtvé tělo (ang. corse od lat. corpus, ne běžný výraz body) položili rozmarýnu. Středověk chápal rozmarýnu jako „růži Mariinu“ pro její neproměnně zelenou barvu. Ze slov Lorenzovy konsolace (4.4.103-10) onomatopoicky proznívá jméno Panny ve slovech panna, vdaná, rozmarýna a radost - maid $(2 \times)$, married $(4 \times)$, rosemary a merriment.

18) Izaiáš 53:3-10: Tytéž výrazy despised, distress se objevují v doayském překladu.

19) Upravený překlad J. V. Sládka (1899). In W. S. Tragédie I. , přel. J. V. Sládek. Praha: SNKLU 1962, s. 387. 
Imaginací pašijového týdne navazují další výjevy. Intermezzo s muzikanty. Právě když Julii vynášejí na márách, přicházejí muzikanti zahrát na svatbu. U brány s nimi mluví Petr a žádá je, aby hráli zvesela, protože jeho „srdce je plné žalu“ (My heart is full of woe). Srov. Mt 26:38: „Smutná jest duše má až k smrti“. Petr dává postupně třem muzikantům hádanku, proč se o hudbě ř́ká, že její zvuk je stříbrný (music with her silver sound) a přitom jim hrozí, že jim svou dýku či mečík zatne do temene (will I lay the serving-creature's dagger on your pate). Pozoruhodný detail upomíná na apoštola v Getsemanech (J 18:10: „Šimon Petr maje meč..."). Vyluštění hádanky, že muzikantům „se zlatem neplatí“, a proto „hudby stříbrozvuk“ (4.4.161), upomíná v situačním i jazykovém kontextu Jidášových třicet stř́ibrných, nebot výraz silver se v rozhovoru $8 \times$ za sebou opakuje! Archetyp Jidáše snad může naznačovat ziskuchtivé motivy Kapuletů namluvit Julii hraběte Parise, namísto zchudlého Monteka, ale v obecnějším smyslu jejich zlost na Julii, kterou jsme popsali výše (3.5).

Nemělo by nás zmást, že $\mathrm{v}$ pozdně středověkých alegoriích a moralitách se biblické prototypy objevují jen zčásti a že přecházejí z jedné postavy na jinou. Přesvědčivě to ukazuje Milward ${ }^{20}$, když na základě biblických citací ukazuje v Learovi rysy Joba i ztraceného syna z podobenství. Julie, podobně jako Dantova Beatrice, jeví v první části hry určité znaky Panny Marie, kdežto ve 3. a 4. dějství ji zrada nejbližších, osamění, domněle absolutní smrt a oplakávání transponuje do figury pašijového Krista. S Marií v čase zvěstováníji spojuje věk (čtrnáct let), předpovědi utrpení (ang. fourteen je homofonní s for teen, tj. „pro utrpení, kvůli utrpení"), dále homofonie zkrácené průpovědi „při Marii“ (Marry), významem pokleslé na citoslovce „na mou věru“, a slovesa „vdáti se“ (merry), na kterou upozorňuje sama Kapuletová větou: "Marry, that ,marry" is the very theme I came to talk of" (1.3). Dalším znakem je ozdoba Juliina těla rozmarýnou. Prototyp apoštola Petra zase přechází z Chůvy (3.5) na sluhu Petra (4.4-5) a v posledním obrazu hry zase na otce Lorenza, když hořce lituje, že kvůli nenadálému hluku se dal vylekat a Julii v hrobce opustil, a jinou chybu vykonal, když snoubence dříve tajně oddal (5.3.261-6).

Hra nenápadně rozvíjí alegorický tropus života jako pouti do chrámu. Nezapomínejme, že Peter's Church znamená v angličtině Petrův kostel i Církev. Pout není zobrazena jako místní pohyb, ale jako pohyb v čase. To naznačují

20) MILWARD, Peter, Biblical Influences in Shakespeare's Great Tragedies, s. XI. Milwardova kniha bohužel nezkoumá Romea a Julii, ale jen Hamleta, Macbetha, Krále Leara a Othella. 
naříkavá slova Kapuletové nad „mrtvou“ Julií: „Nejneštastnější hodina, jakou kdy viděl čas / v lopotném ploužení své pouti“ (Most miserable hour that e'er time saw / In lasting labour of his pilgrimage! - 4.5.76). Romeo se neubírá do Ríma $\mathrm{k}$ ostatkům apoštola, ale, třeba i nevědomky, s Julií k Petrově bráně do nebeského velechrámu. Julie vypije nápoj a čeká, že „s ránem přijde ženich“, jak slíbil kněz. Vstane třetího dne po svém očištění zpovědí a Lorenzovým rozhřešením, obvykle spojeným s přijetím nejsvětější svátosti, a její čin je stejnou měrou motivován touhou po splynutí s Romeem, jakož i snahou uniknout druhému, svatokrádežnému sňatku, $\mathrm{k}$ němuž je nucena vůlí obou rodičů (to rid her from the second marriage). Potvrzuje to svědectví „svatého muže“ před veronským vévodou Eskalem (5.3.269). Romeo má, i přes všechny hříchy horkokrevné vášně, skrze svátostné spojení manželské přístup k vykoupení. Neklamné znamení finálního vykoupení „milenců, jimž hvězdy zkřížily cestu“ (star-cross'd lovers) je patrné z toho, že svou smrtí „pohřbili osudnou nenávist svých příbuzných“a zemřeli, jak uzavírá Kapulet, jako „ubohé oběti našeho nepřítelství“ (poor victims), pročež má Veronu ozdobit jejich zlatá socha (motiv v puritánském Londýně exotický a, pochopitelně, rouhavý).

Politický a sociální dosah usmíření znepřátelených veronských frakcí vychází z manželské svátosti a potvrzuje její platnost a mystické působení. Podle kanonické formy Lorenzových slov jsou Romeo s Julií spojeni dva do jednoho těla (incorporate two in one, 2.6.37), a tím už překonali rozdělení těla veronské polis. Řeholníkova zbožná intence „obrátit zášt rodů v čistou lásku“ (2.2.92) se tím naplní, ale zpo̊sobem, jehož se nikdo nenadál. Tragický skon milostného páru ale způsobil nakonec proměnu ne nepodobnou té, kterou končí Dantův Nový život: obrazem města zarmouceného smrtí Beatrice a vdechnutím nové inteligence odpouštějící lásky, která je duchovním vycházením vstříc Bohu a bližnímu, tím, co Dante nazývá „poutnickým duchem“ (spirito peregrino).

Třebaže tento itinerář pouti Romea s Julií $\mathrm{k}$ Bohu má $\mathrm{v}$ textu hry poměrně malou textovou oporu a zavisí na čtenářském domýšlení, neměli bychom jej a priori zamítat, a to zvláště ve světle Shakespearovy básně Fénix a holoubek (1601) a její vize mystického spojení manželů na věčnosti, kdy jeden každý splývá s duší druhého (Either was the other's mine), takže dvě osobní jména už pak označují jedinou sdílenou přirozenost (Single nature's double name) ${ }^{21}$

21) Srov. FINNIS, John, MARTIN, Patrick, „Another turn for the Turtle“. Times Literary Supplement, April 18, 2003, s. 12-14. Autoři ukazují, že báseň je requiem na smrt manželů Rogera a Ann Line(ových) pronásledovaných pro katolickou víru. Zemřeli odděleně: Roger Line ve Francii, Ann na Tyburnu. 
Alžbětinské publikum bylo obecně nábožensky založeno a úvaha o posmrtném životě divadelních postav nebyla pro ně násilně imputovanou interpretací, nýbrž běžným návykem.

\section{Conclusio}

Náš článek se pokusil nejdříve osvětlit politické, náboženské, věcné a jazykové souvislosti, které v době jejího uvedení vstupovaly do sémantiky Shakespearovy hry. Dále prozkoumal odkazy ke sv. Petru, alegorie Petra v okovech, obraz Petra Klíčníka a především alegorický tropus Petrova zapření Páně ve velikonočním kontextu Zeleného čtvrtku a Velkého pátku, v němž postava Julie nabývá alegorických rysů Beránka obětovaného za mír obce. Hra sice neztratí svou dramatickou kvalitu a básnickou přitažlivost ani bez znalosti těchto specificky křestaanských odkazů, ale při konkrétním inscenování hrozí jejich potlačení a celková dezinterpretace. Shakespearovy př́hodné alegorizace a biblické paralelismy ukazují, jakým způsobem přistupoval k svým předlohám, jaké adresáty v publiku hledal a jaké poselství jim chtěl předat.

\section{PRAMENY}

BIBLE, Douay-Rheims Bible

1582-1609 URL: http://www.drbo.org/

\section{SHAKESPEARE, William}

1997 The Most Excellent and Lamentable Tragedy of Romeo and Juliet, in The Norton Shakespeare, Greenblatt, S. - Cohen, W. - Maus, K. Eisaman eds., 1. vyd. (New York: Norton), s. 872-941

\section{LITERATURA}

\section{BULLOUGH, Geoffrey}

1957 Narative and Dramatic Sources of Shakespeare, vol. 1 (London: Routledge and Paul)

\section{DRÁBEK, Pavel a kol.}

2010 Kapradí - knihovna prekladů raného anglického dramatu (Brno: Masarykova Univerzita), URL: http:// www.phil.muni.cz/kapradi/ 
Petr Osolsobě

Alegorie a odkazy k apoštolu Petrovi v Shakespearově Romeovi a Julii

1987 Biblical Influences in Shakespeare's Great Tragedies (Bloomington: Indiana University Press)

OSOLSOBĔ, Petr

2002 „How Could Shakespeare Know There Was a St. Luke in Padua?“ SPFFMU, H 36-37 (Brno: Masarykova univerzita), s. 117-125

2016 „Př́tomnost Edmunda Campiona v Shakespearových hrách“, Kontexty, 2014, 6 (Brno: Centrum demokracie a kultury), s. 52-61

PAINTER, William

1890 The Palace of Pleasure, Jacobs, Jos. ed., vol. 3 (London: Ballantyne Press), URL: http://www.gutenberg. org/files/20241/20241-h/20241-h.htm

SIMPSON, Richard

1875 „On Evening Mass in Romeo and Juliet, IV, 1, 38“, in The New Shakespeare's Society Transactions (London: Trübner \& Co.), s. 148-152

1907 Edmund Campion, Jesuit Protomartyr of England, 2. vyd. (London: Burns \& Oates)

SIMPSON, Richard - BOWDEN, Henry

1899 The Religion of Shakespeare (London: Burns \& Oates)

Prof. PhDr. Petr Osolsobě, Ph.D., petr@phil.muni.cz, Seminár̆ estetiky, Masarykova univerzita, Brno, Česká republika / Department of Aesthetics, Faculty of Arts, Masaryk University, Brno, Czech Republic 